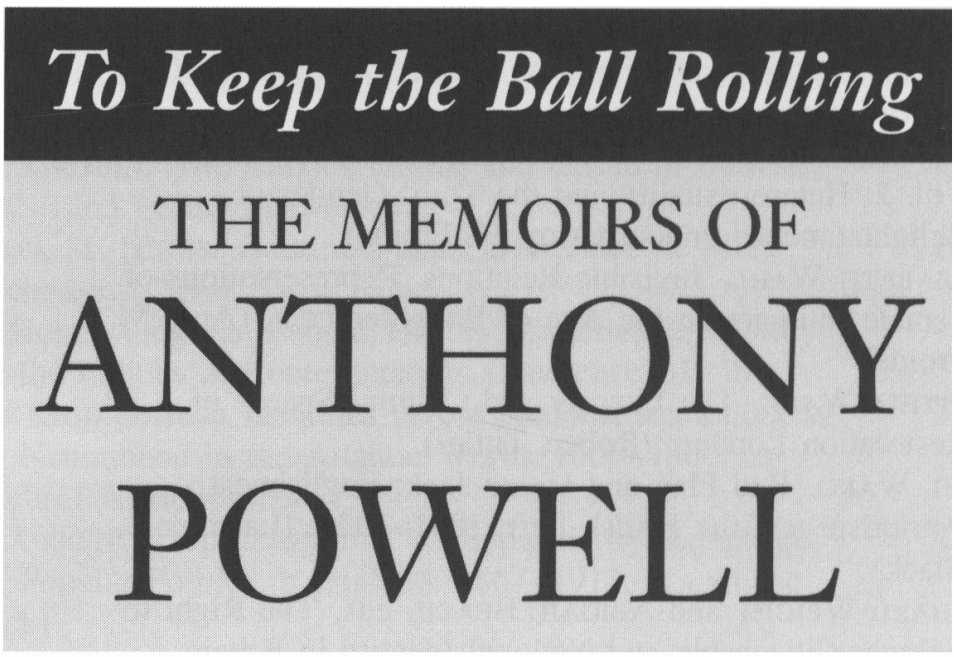

WITH A FOREWORD BY FERDINAND MOUNT

Cloth $\$ 27.50$

"One of the finest of contemporary autobiographies."

-Roy Fuller, Sunday Times

"Powell was indeed a literary giant, and eminently deserving of the praise that was lavished on him."

-The Wall Street Journal

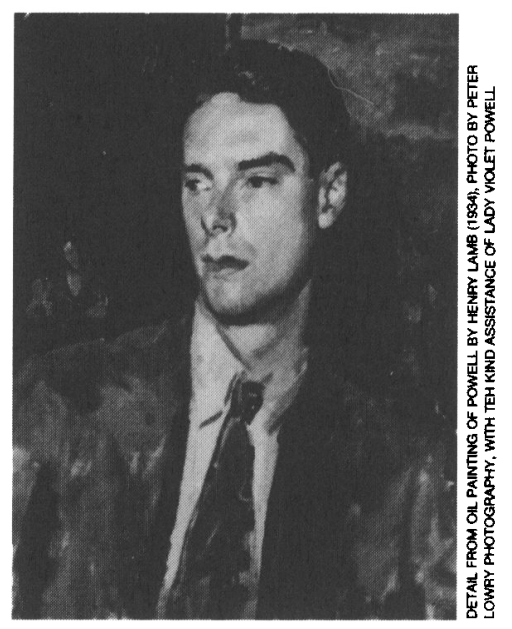

"A master of wit, paradox, and social delineation." -The New York Times 


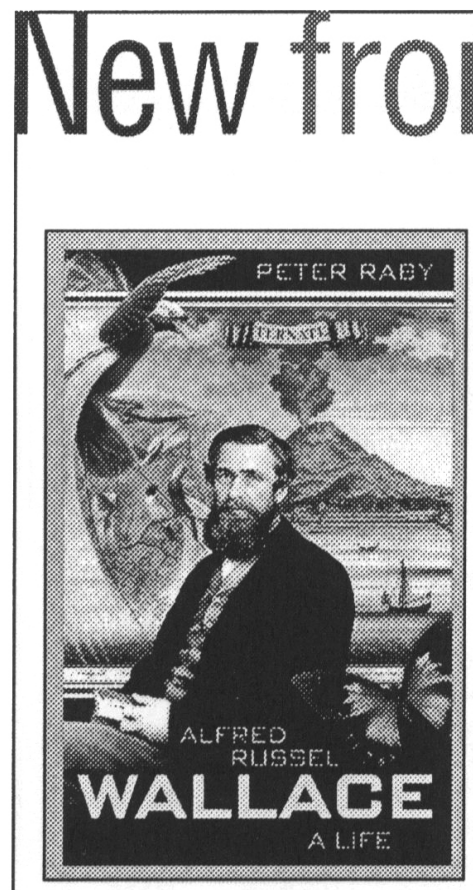

\section{Alfred Russel Wallace}

A Life

\section{Peter Raby}

This new biography of Alfred Russel Wallace traces the development of one of the most remarkable scientific travelers, naturalists, and thinkers of the nineteenth century. With vigor and sensitivity, Peter Raby reveals his subject as a courageous, unconventional explorer and a man of exceptional humanity. He draws more extensively on Wallace's correspondence than has any previous biographer and offers a revealing yet balanced account of the relationship between Wallace and Charles Darwin.

"An excellent and inspiring read." -Hannah Atkins, New Scientist

Cloth \$26.95 ISBN 0-691-00695-4

Not available from Princeton in the U.K. and E.U

\section{New in paperback}

\section{Shopping for Pleasure}

Women in the Making of London's West End Erika Diane Rappaport

In Shopping for Pleasure, Erika Diane Rappaport reconstructs London's Victorian and Edwardian West End and shows how shopping came to be seen as the quintessential leisure activity for middle- and upper-class women.

"A fascinating as well as an erudite book." -Elaine Showalter, London Review of Books

"A thoughtful and accessible study that illuminates the period in a new and colorful way." - Lynne Truss, Sunday Times

Paper \$18.95 ISBN 0-691-04476-7 Due October

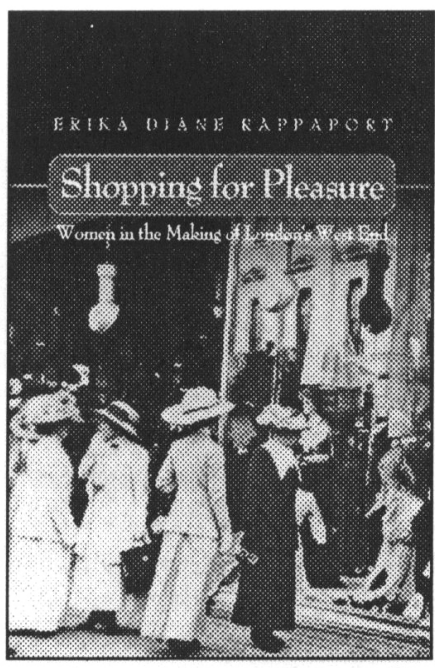

\section{Фఠ Princeton University Press}

800-777-4726 • WWW.PUP.PRINCETON.EDU 


\section{New and Noteworthy from Cambridge}

Bagehot: The English Constitution

Walter Bagehot

Poul Smith, Editor

Cambridge Texts in the History of Political Thought

0-521-46535-4 Hardback \$54.95

0-521-46942-2 Paperback \$19.95

\section{Lord Salisbury's World}

Conservative Environments in

Late-Victorian Britain

Michael Bentley

0-521-44506-X Hardback \$44.95

\section{Negotiating Power in}

Early Modern Society

Order, Hierarchy and Subordination in

Britain and Ireland

Michael J. Braddick and John Walter, Editors

0-521-65163-8 Hardback \$59.95

\section{Redcoats}

The British Soldier and War in the

Americas, 1755-1763

Stephen Brumwell

0-521-80783-2 Hardback \$34.95

\section{Pedagogy, Intellectuals, and} Dissent in the Later Middle Ages

Lollardy and Ideas of Learning

Rita Copeland

Cambridge Studies in Medieval Literature 44

0-521-65238-3 Hardback \$64.95

\section{The Cambridge Companion to}

\section{Spenser}

Andrew Hadfield, Editor

Cambridge Companions to Literature

0-521-64199-3 Hardback \$54.95

0-521-64570-0 Paperback \$19.95

\section{A Nation Transformed}

England after the Restoration

Alan Houston and Steve Pincus, Editors

0-521-80252-0 Hardback \$54.95

\section{Royalty and Diplomacy in}

Europe, 1890-1914

Roderick R. McLean

New Studies in European History

0-521-59200-3 Hardback

$\$ 54.95$
The Heads of Religious Houses

England and Wales, I. 940-1216

Second Edition

David Knowles, C.N.L. Brooke, and

Vera C.M. London, Editors

0-521-80452-3 Hardback \$64.95

England and Wales, II. I 2 16- 1377

David M. Smith and

Vera C.M. London, Editors

0-521-80271-7 Hardback

$\$ 120.00$

\section{The Putney Debates of 1647}

The Army, the Levellers, and the English State Michael J. Mendle, Editor

0-521-65015-1 Hardback \$64.95

\section{Imagining Early Modern London}

Perceptions and Portrayals of the City from Stow to Strype, 1598- 1720

J.F. Merritt, Editor

0-521-77346-6 Hardback \$59.95

\section{Slavery, Atlantic Trade} and the British Economy, 1660-1800

Kenneth Morgan

New Studies in Economic and Social History 42

0-521-58213-X Hardback \$39.95

0-521-58814-6 Paperback \$11.95

\section{Empire on the}

Restoration Stage

Bridget Orr

0-521-77350-4 Hardback \$59.95

\section{The Labour Party and Taxation}

Party Identity and Political Purpose in

Twentieth-Century Britain

Richard C.Whiting

0-521-57160-X Hardback \$64.95

Now in paperback...

The Cambridge Illustrated History of the British Empire

P.). Marshall, Editor

Cambridge Illustrated Histories

0-521-00254-0 Paperback \$34.95 


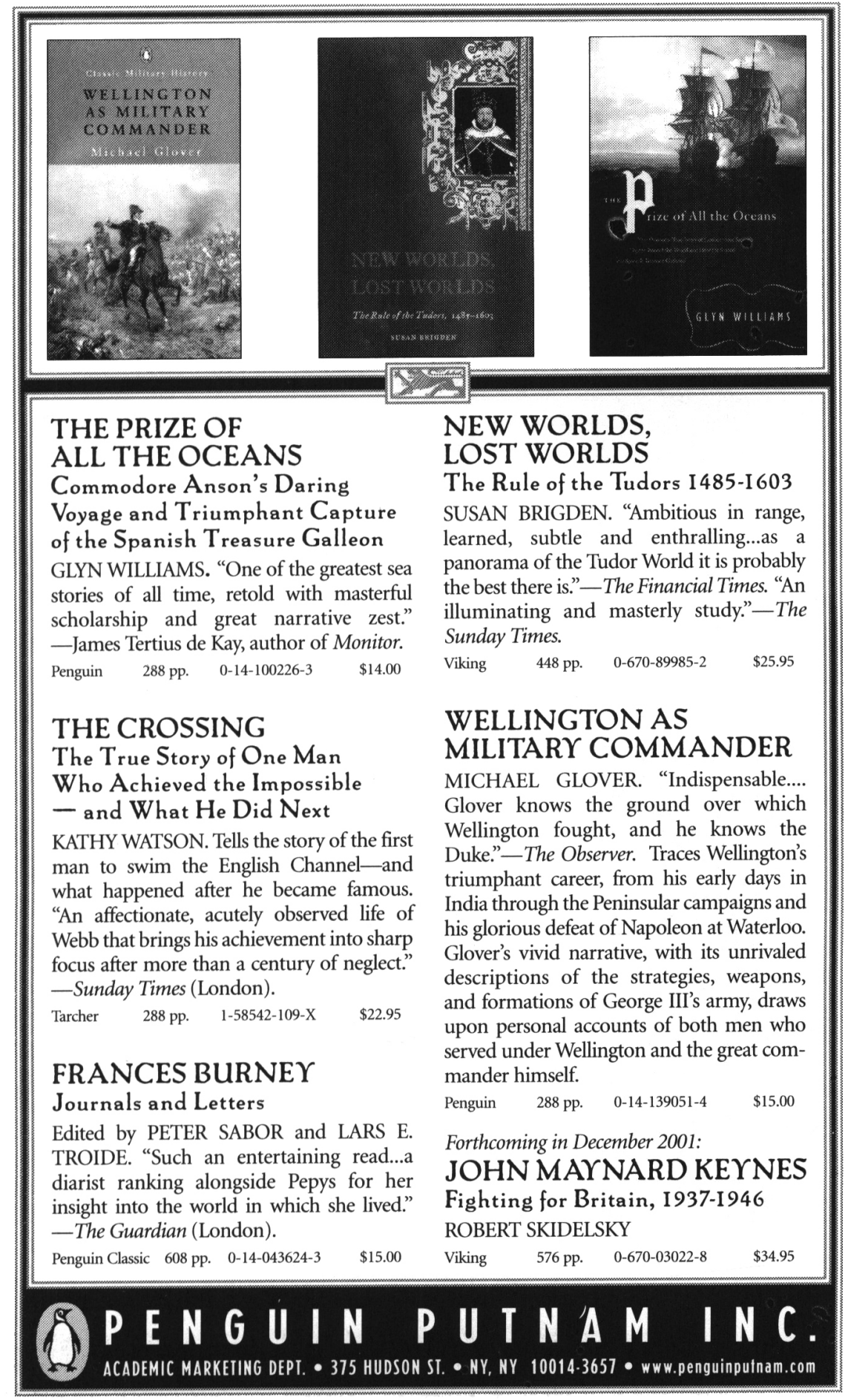




\section{British Lives and Times}

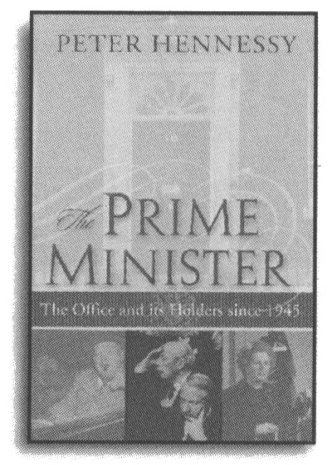

\section{The Prime Minister}

The Office and Its Holders Since 1945

\section{Peter Hennessy}

"An entertaining and fiercely researched account by the leading authority on British executive government."

- The Economist 686 pp. / 0-312-29313-5/ \$45.00 cl.

$16 \mathrm{pp} . \mathrm{b} / \mathrm{w}$ photo insert

\section{A Frigate of King George}

Life and Duty on a British Man-of-War

\section{Brian Vale}

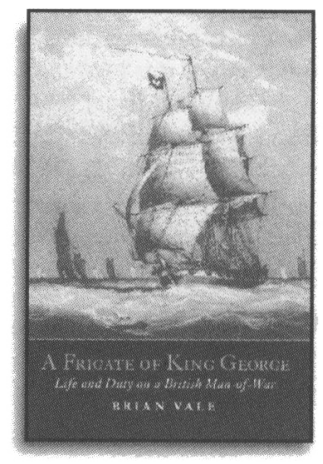

This account of life on board the 42-gun frigate HMS Doris, from Bombay in 1807 to Valparaiso in 1829 , concentrates on the ship's service under Thomas Hardy as she protected British interests during the years of South American Independence.

224 pp. / 1-86064-654-9 / \$35.00 cl.

I.B.Tauris

\section{Politics and Empire in Victorian Britain \\ A Reader \\ Edited by Antoinette Burton}

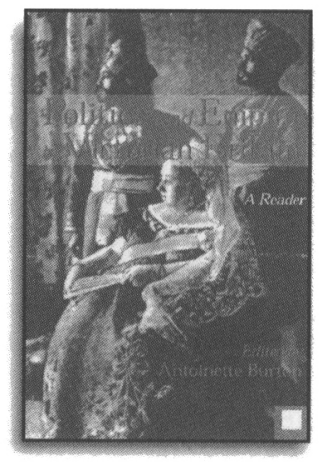

This is the first source book to track the role the British Empire played in domestic politics, social attitudes, and intellectual and cultural life. The book introduces the intersections of "home" and "empire" so that the effects of imperialism on Victorian politics and society can be fully appreciated.

368 pp. / 0-312-29335-6 / \$24.95 pb.

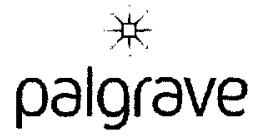

Global Publishing at St. Martin's Press

1-800-221-7945 ext. 270 - www.palgrave-usa.com

Distributors of I.B.Tauris, Manchester University Press and Zed Books 


\section{New from}

\section{WAR DIARIES 1939-1945}

Field Marshal Lord Alanbrooke Edited by Alex Danchev \& Daniel Todman For most of the Second World War Lord Alanbrooke, was Britain's Chief of the Imperial General Staff and Winston Churchill's principal military adviser, and antagonist, in the inner councils of war. His diaries - published here for the first time in complete and unexpurgated form-are one of the most important and the most controversial military diaries of the modern era. $\$ 40.00$ cloth

\section{THE WAR COME HOME}

Disabled Veterans in Britàin and Germany, 1914-1939

\section{Deborah Cohen}

"With verve, compassion, and...clarity, The War Come Home makes the dismal story of the failed reconstructions of disabled veterans in interwar Britain and German into engaging and provocative reading."

- Seth Koven, coeditor of

$\$ 50.00$ cloth Mothers of a New World

\section{BRITISH COMMENT ON THE UNITED STATES}

A Chronological Bibliography, 1832-1899

Ada B. Nisbet

Edited by Elliot J. Kanter

With a Foreward by Asa Briggs

This bibliography of more than three thousand entries, often extensively annotated, lists books and pamphlets that illuminate evolving British views on the United States.

UC Publications in Catalogs and Bibliographies $\$ 85.00$ cloth

\section{California}

\section{UNDERTAKER OF THE MIND}

John Monro and Mad-Doctoring

in Eighteenth-Century England

Jonathan Andrews \& Andrew Scull

"The most splendid piece of original research for many a year on the early history of British psychiatry.... Absolutely essential reading!" - Roy Porter, author of The Creation of the Modern World Medicine and Society, $\$ 35.00$ cloth

\section{THE PERREAUS AND MRS. RUDD}

Forgery and Betrayal

in Eighteenth-Century London

\section{Donna T. Andrew \& Randall McGowen}

"Stunningly wrought. Anyone with the slightest interest....in London or eighteenth century England could not fail to be intrigued by the stories of two identical twin brothers... who die hand-in-hand on the gallows."

- Thomas Laqueur, author of Making Sex

$\$ 35.00$ cloth

\section{New in Paperback}

SECURE FROM RASH ASSAULT

Sustaining the Victorian Environment James Winter

"[A] richly detailed, well-researched survey of the impact of industrialization and urbanization on the environment of nineteenth-century Biritain."
- American Historical Review
$\$ 22.50$ paper

\section{IN SEARCH OF ENGLAND}

Journeys into the English Past

\section{Michael Wood}

"As a cameo of modern Englishness, it is brilliant."-Times Literary Supplement \$16.95 paper

At bookstores or order (800) 822-6657 - www.ucpress.edu UNIVERSITY OF CALIFORNIA PRESS 


\section{"The single best guide to academe I have ever read." *}

\section{John A. Goldsmith, John Komlos, And Penny Schine Gold}

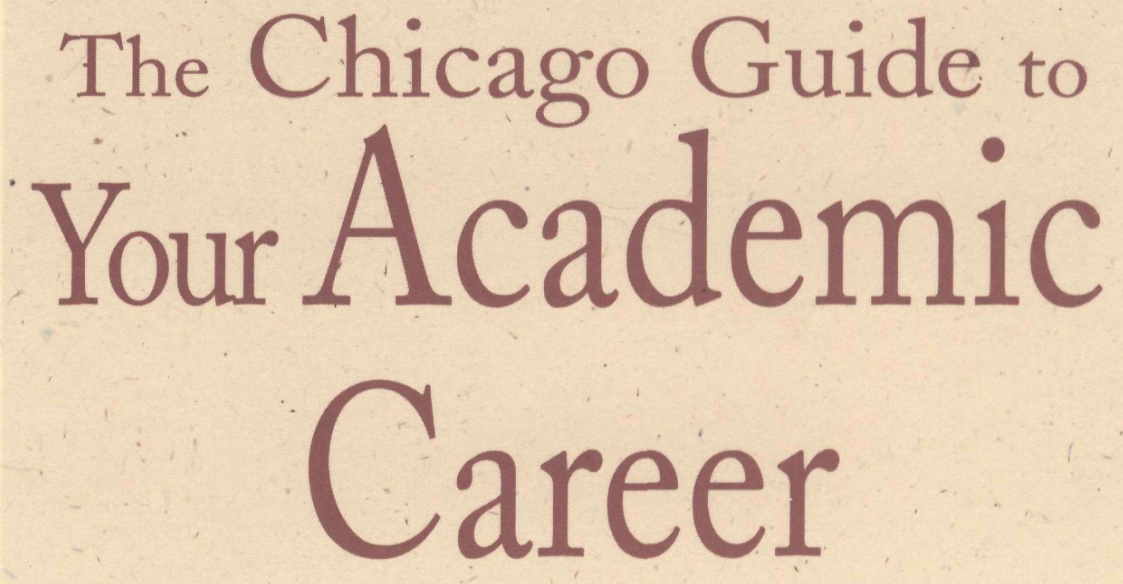

\section{A Portable Mentor for Scholars from Graduate School through Tenure}

“Why wasn't The Chicago Guide to Your Academic Career around when I was first starting out? It could certainly have quickly cleared up a great deal of mystification-and saved me a lot of hearfache. The authors, in no-nonsense readable prose, help hopefuls navigate what we know are the uncommonly treacherous (though deceptively calm) waters of academic careers. From the first glimmer of ambition to the all-important game plan for promotion and tenure, wise and compassionate colleagues use their own and others' experiences to help give neophytes their best shot at survival-and success."

-Pepper Schwartz; University of Washington

Paper $\$ 13.00$

*Peter A. Coclanis, University of North Carolina, Chapel Hill

The University of Chicago Press

142Z East 60th Street, Chicago, IL 60637 • www.press.uchicago.edu

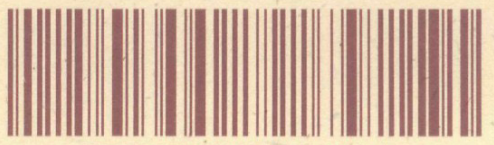

